九州大学学術情報リポジトリ

Kyushu University Institutional Repository

\title{
NEW OR LITTLE KNOWN BEES OF JAPAN (HYMENOPTERA, APOIDEA). III. PASITES ESAKII, A GENUS AND SPECIES NEW TO JAPAN
}

Hirashima, Yoshihiro

Nagase, Hirohiko

https://doi.org/10.5109/2413

出版情報 : ESAKIA. 17，pp.49-52，1981-11-30. Entomological Laboratory，Faculty of Agriculture， Kyushu University

バージョン：

権利関係 : 


\title{
NEW OR LITTLE KNOWN BEES OF JAPAN (HYMENOPTERA, APOIDEA). III. PASITES ESAKII, A GENUS AND SPECIES NEW TO JAPAN*
}

\author{
YOSHIHIRO HIRASHIMA \\ Entomological Laboratory, Faculty of Agriculture, \\ Kyushu University, Fukuoka 812, Japan \\ and \\ H IROHIKO N A GASE \\ 81 Nikaido, Kamakura 248, Japan
}

\begin{abstract}
The bee genus Pasites is recorded from Japan for the first time. Pasites esakii, which has been treated as one of the subspecies of P. maculatus Jurine, is raised to the species rank. Pasites esakii is thought to be parasitic on Pseudapis mandschurica (Hedicke), formerly included in the genus Nomia.
\end{abstract}

In the early autumn of 1980, one of the authors, Nagase, was lucky enough to collect three female specimens of Pasites together with a number of male and female specimens of its probable host bee species Pseudapis mandschurica (Hedicke), at Kanoya City, Kagoshima Pref., Kyushu. This is the first discovery of Pasites from Japan.

The species was later identified as Pasites maculatus esakii Popov et Yasumatsu described from N. E. China (then called Manchuria). However, this is regarded as a distinct species as stated below.

Pasites esakii Popov et Yasumatsu, new status

Pasites maculatus esakii Popov et Yasumatsu, 1935, Mushi, $8: 101$.

The original description of esakii states that this is based on three female specimens collected at Dairen (Dalny), and the male is unknown. However, the holotype deposited in the collection of Kyushu University is a male, not female.

* Contribution from the Entomological Laboratory, Faculty of Agriculture, Kyushu University, Fukuoka (Ser. 3, No. 93). 
Although the habitus is very similar, the holotype male of esakii markedly differs from a male specimen of Pasites maculatus ashabadensis (Radoszkowsky) (collected at Dugas near Chami, S. E. of Tian-Shan, determined by Popov, but also determined by Friese as maculatus var. brunneus Friese before Popov) as

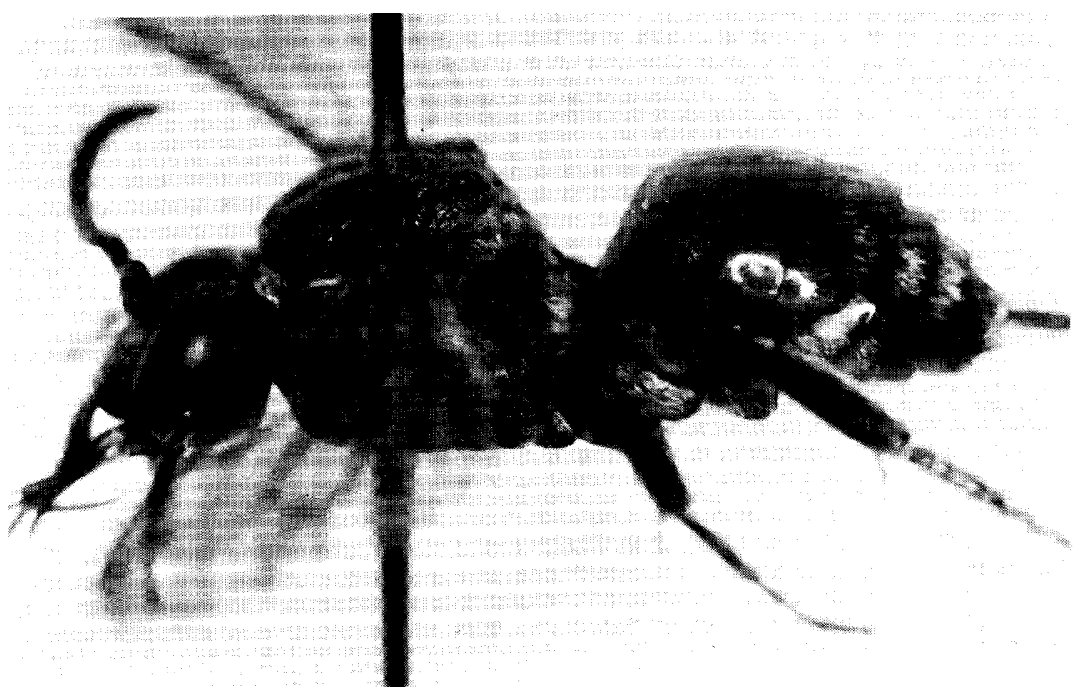

Fig. 1. Pasites esakii, 우, latero-dorsal view.

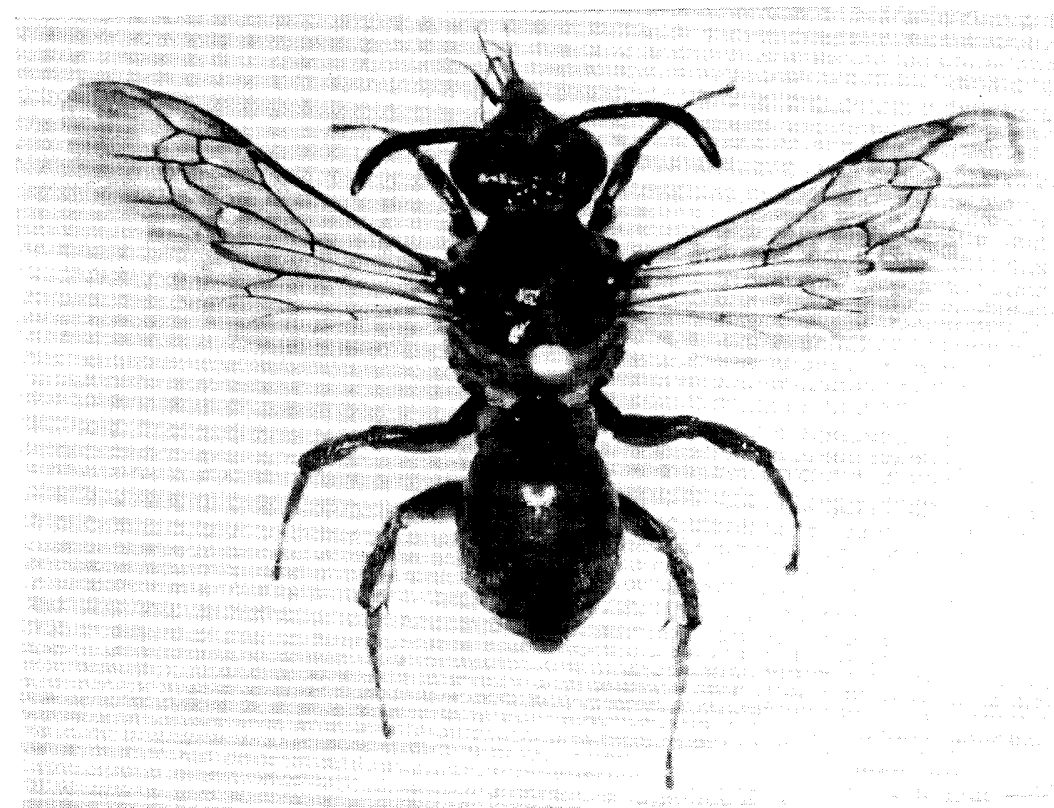

Fig. 2. Pasites esakii, 우, dorsal view. 
follows :

Head, including antennae, thorax, legs and metasoma (except two red basal terga) nearly all black (body entirely red with several slightly darkened portions in ashabadensis) ; appressed white hairs on head and thorax much sparser and dull (very dense and silvery in ashabadensis) ; frons lateral to fronal line more deeply concave; clypeus (especially on apical portion) and face lateral to it more elevated, and more strongly punctate; mesoscutum much less depressed along the median mesoscutal line, especially on apical portion ; punctures on mesoscutum stronger and closer; scutellum much less strongly bigibbous; legs, especially the mid and hind pairs, more robust; 1st tergum large and more convex basally (1st tergum about as long as in esakii, but less convex basally in ashabadensis), apical margin of 1 st tergum notched in the middle, although very slightly so (apical margin entire in ashabadensis) ; and apical margins of 2nd to 6th terga emarginate in the middle (entire in ashabadensis). Genitalia not examined.

Four female specimens of esakii, 3 from Japan (Kyushu) and 1 from N. E. China (no data except " 8 viii" which means August 8), differ from a female of ashabadensis (the same data as the male mentioned above) as follows:

Body nearly all black except for two basal terga red (entirely red with a transverse dark band on ocellar region only in ashabadensis) ; lower half of face (including clypeus) less shining with stronger punctures; frons more deeply depressed in the middle; space between upper portion of eye and lateral ocellus nearly flat or slightly concave (more convex, although slightly so, in ashabadensis), with large impunctate space lateral to lateral ocellus ; punctures on mesoscutum weaker and slightly denser; scutellum much less strongly bigibbous; appressed silvery hairs on thorax sparser and less extensive ; legs slightly stouter ; 1st tergum with weaker and sparser punctures on basal portion; apical margin of 2nd tergum slightly emarginate in the middle (entire in ashabadensis, although apical margins of 3rd to 5th terga slightly emarginate in the middle as in esakii); and apical fossa of 5th sternum (a hole for the sting and ovipositor) large and distinctly elongate (the fossa distinctly shorter, therefore more rounded in ashabadensis).

Two females from Turkmenia, determined by Popov as Pasites maculatus ashabadensis, are much smaller, and also markedly different from our females of esakii.

A male of Pasites maculatus ashabadensis from Turkestan, also determined by Popov, has the head and thorax more darkened than in the male from TsianShan mentioned above, but is still distinctly different from the holotype male of esakii.

A female from Irkutsk, Siberia, determined as Pasites maculatus by Popov, has the head and thorax broadly darkened, but not entirely black as in ours, and the apical fossa of 5 th sternum also large as in esakii, but still differs 
from the latter in having the different coloration, different puncturation (for example, punctures on 1st tergum much stronger than in esakii) and different other structures (for example, the apical margins of 2nd to 5th terga entire).

In addition to the characters mentioned above, the apical portions of 2 nd to 5th terga in female and those of 2nd to 6th terga in male of esakii broadly flat or slightly concave (especially on lateral portions), and the apical margins of these terga slightly reflected. This is distinctive for esakii and not seen in any of the above mentioned specimens of maculatus and $m$. ashabadensis.

Thus, we think esakii may be regarded as a good species and it is treated as such in this paper.

It is very interesting to note that the antennae are 12-segmented in both sexes in this genus. This is unusual for the bees. In addition, the sexual difference is also very slight except for the genitalia and the modification of the apical part of metasoma. Pasites esakii is not exceptional.

Specimens examined: 1 female, September 14, and 2 females, September 15, 1980, Kanoya City, Kagoshima Pref., Kyushu (H. Nagase) ; 1 female, August 8, N. E. China (no further data).

Distribution: N. E. China and Japan (Kyushu).

HABitat AND HOST: In Kanoya City, the site of collection was restricted to a small section of flat land mainly cultivated for field crops with some uncultivated area along the margin. It was unique in that a fairly rich population of Pseudapis mandschurica (Hedicke) was exclusively found in the section. At the same time, Tetralonia mitsukurii Cockerell, Triepeolus ventralis (MeadeWaldo) and a few species of small Lasioglossum were found in the same section. The mode of occurrence of bee species in Kanoya City strongly suggests that Pasites esakii is a parasite of Pseudapis mandschurica. In Europe, Pasites maculatus is known to be parasitic on diversipes and other species of Pseudapis (formerly known as Nomia).

In mid-September, Pseudapis females were in full activity, while the specimens of Pasites collected at that time were all worn out to some extent on the wing margins, and no male was found. These facts may suggest that the peak activity period of the two bees do not exactly coincide, as often observed in other parasitic bees such as Nomada.

Aстіviт: A quiet, low, daytime flier, like species of Epeolus or Triepeolus.

Flower record: Scilla scilloides (Jap. name, Tsurubo) and Kalimeris yomena (Jap. name, Yomena).

\section{Reference}

Popov, V. B. and K. Yasumatsu. 1935. Notes on the bee genus Pasites Jurine (Hymenoptera, Nomadidae) with description of a new subspecies of $\boldsymbol{P}$. maculatus Jurine from south Manchuria. Mushi,8: 97-104, 1 pl. 